\title{
HUBUNGAN PENGGUNAAN GADGETDENGAN KEJADIAN INSOMNIA PADA SISWA SISWI KELAS X SMA NEGERI 9 KOTA TANGERANG SELATAN
}

\author{
Lela Kania, Sigit Probowani \\ Sekolah Tinggi Ilmu Kesehatan Kharisma Persada \\ Tangerang Selatan, 15417 \\ E-mail :lila.kania@gmail.com
}

\begin{abstract}
ABSTRAK
Salah satu penyebab terjadinya insomnia pada remaja yang paling sering disebabkan oleh faktor kebiasaan seperti gaya hidup remaja yang haus akan teknologi terutama dalam penggunaan gadget. Penelitian ini bertujuan untuk mengetahui hubungan penggunaan gadget dengan kejadian insomnia pada remaja kelas X di SMA Negeri 9 Kota Tangerang Selatan. Penelitian ini menggunakan studi korelasi dengan pendekatan waktu cross sectional. Responden penelitian adalah 103 responden seluruh siswa siswi kelas X SMA Negeri 9 Tangerang Selatan menggunakan teknik proportional stratified random sampling. Intensitas penggunaan gadget diukur dengan kuesioner nilai reliabilitas 0,862 dan insomnia diukur dengan kuesioner nilai reliabilitas 0,769. Analisa data menggunakan Chi Square. Hasil analisa data dengan Chi Square dengan nilai p sebesar $0,000(\mathrm{p}<0,05)$, menunjukkan bahwa tidak terdapat hubungan antara intensitas penggunaan gadget dengan insomnia pada remaja di SMA Negeri 9 Kota Tangerang Selatan.
\end{abstract}

Kata kunci : Gadget, Insomnia, Siswa kelas X

\begin{abstract}
One of the causes of insomnia in adolescents is most often caused by habit factors such as adolescent lifestyles who are hungry for technology especially use of gadgets. This study aims to determine the relationship of use of gadgets with the incidence of insomnia in adolescents class X in SMA Negeri 9 Tangerang Selatan. This study used correlation study with cross sectional time approach. Research respondents are 103 respondents of all students of grade X SMA Negeri 9 Kota Tangerang Selatan using proportional stratified random sampling technique. The intensity of gadget usage was measured by the reliability value questionnaire of 0.862 and insomnia was measured by the reliability value questionnaire of 0.769. Data analysis using Chi Square. Result of data analysis with Chi Square with p value of 0.000 ( $p<0,05)$, showed that there was no correlation between intensity of use of gadgets with insomnia in adolescent in SMA Negeri 9 Kota Tangerang Selatan.
\end{abstract}

Keywords: Gadget, Insomnia, Student Grade X 


\section{PENDAHULUAN}

Gadget juga menjadi salah satu kebutuhan utama untuk menunjang aktifitas sehari-hari. Citra merek dan kualitas pada produk-produk gadget juga menjadi pertimbangan bagi masyarakat untuk membelinya. Penggunaan gadget berjam-jam dapat melupakan aktifitas lainnya (Fadilah, 2011).

Terkait pengguna gadget, Indonesia termasuk 5 besar Negara komsumen gadget aktif setelah China, India dan Amerika Serikat, Brazil dan Indonesia. Hampir setiap orang sekarang memegang gadget setiap waktunya dan memiliki gadget lebih dari satu, gadget yang.dimiliki hamper seluruhnya tersambung internet dan aktif tiap waktu (Internet world stats, 2018).

Menurut Direktur Jendral Aplikasi Informatika Kementrian Komunikasi dan Informatika (Kominfo), pada tahun 2015 pengguna ponsel di tanah air diperkirakan ada 270 juta gadget digunakan oleh penduduk Indonesia yang sudah melebihi penduduk Indonesia yang hanya sekitar 250 juta jiwa. Sedangkan penggunaan gadget di Indonesia di dominasi oleh remaja berusia 15-19 tahun sebesar $80 \%$ (Siaran Pers Kominfo, 2014). Studi yang dilakukan oleh UNICEF dan bekerja sama dengan Indonesia melalui Kominfo menyebutkan bahwa setidaknya 30 juta anak-anak dan remaja di Indonesia merupakan pengguna internet. Hasil studi menemukan bahwa 80 persen responden merupakan pengguna internet (Kominfo, 2014).

Menurut Direktur Jendral Aplikasi Informatika Kementrian Komunikasi dan Informatika (Kominfo), pada tahun 2015 pengguna ponsel di tanah air diperkirakan ada 270 juta gadget digunakan oleh penduduk Indonesia yang sudah melebihi penduduk Indonesia yang hanya sekitar 250 juta jiwa. Sedangkan penggunaan gadget di Indonesia di dominasi oleh remaja berusia 15-19 tahun sebesar $80 \%$ (Siaran Pers Kominfo, 2014). Studi yang dilakukan oleh UNICEF dan bekerja sama dengan Indonesia melalui Kominfo menyebutkan bahwa setidaknya 30 juta anak-anak dan remaja di Indonesia merupakan pengguna internet. Hasil studi menemukan bahwa 80 persen responden merupakan pengguna internet (Kominfo, 2014).

Orang tidak selamanya dapat menikmati tidur dengan baik. Rata-rata waktu tidur yang dibutuhkan manusia perhari pada usia remaja 12-18 tahun jumlah kebutuhan tidur 8,5 jam perhari. Untuk menjelajah internet sekedar mengakses jejaring sosial seringkali remaja begadang sehingga menyebabkan 
remaja mengalami kurang tidur, walaupun hanya sekedar mengakses atau berinteraksi dengan pengguna lainnya sebelum jam tidur dapat mengganggu pola tidur, memicu insomnia, sakit kepala dan kesulitan konsentrasi (Rafknowledge, 2004).

\section{METODE PENELITIAN}

Desain penelitian yang digunakan dalam penelitian ini adalah Crosssectional dengan rancangan penelitian Chi-Square. Jumlah sampel sebanyak 103 responden, cara pengambilan sampel digolongkan dalam probability sampling dengan menggunakan teknik proportional stratified random sampling. Alat ukur yang digunakan adalah kuesioner. Analisa yang digunakan adalah analisa univariat dan bivariat dengan menggunakan uji Chi-Square.

\section{HASIL}

\section{Hasil Analisis Univariat}

Berdasarkan penelitian yang telah dilakukan di SMAN 9 Kota Tangerang Selatan didapatkan hasil penelitian sebagai berikut :

Tabel 1. Distribusi Penggunaan Gadget

\begin{tabular}{ccc}
\hline Penggunaan Gadget & Jumlah & $\begin{array}{c}\text { Persentase } \\
(\mathbf{\%})\end{array}$ \\
\hline Tidak Intens (<4jam/hari) & 16 & 15,5 \\
Intens (> 4jam/hari) & 87 & 84,5 \\
\hline Total & $\mathbf{1 0 3}$ & $\mathbf{1 0 0 , 0}$ \\
\hline
\end{tabular}

Berdasarkan tabel tersebut, yaitu sebesar $87(84,5 \%)$, dari total didapatkan persentase penggunaan sampel yaitu 103 siswa. gadget dengan intensitas $>4 \mathrm{jam} / \mathrm{hari}$

Tabel 2. Distribusi Lama Penggunaan Jejaring Media Sosial

\begin{tabular}{ccc}
\hline $\begin{array}{c}\text { Lama Penggunaan Jejaring } \\
\text { Media Sosial }\end{array}$ & Jumlah & $\begin{array}{c}\text { Persentase } \\
(\boldsymbol{\%})\end{array}$ \\
\hline Singkat & 28 & 27,1 \\
Sedang & 39 & 37,9 \\
Lama & 36 & 35,0 \\
\hline Total & $\mathbf{7 6}$ & $\mathbf{1 0 0 , 0}$ \\
\hline
\end{tabular}

Berdasarkan tabel tersebut, terendah lama penggunaan jejaring didapatkan persentase tertinggi lama penggunaan jejaring media sosial yaitu sebesar 39 responden $(37,9 \%)$ dengan kategori sedang, sedangkan persentase media sosial yaitu sebesar 28 responden $(27,1 \%)$ dengan kategori singkat dari total sampel yaitu 103 siswa. 
Tabel 3. Distribusi Konsumsi Kafein

\begin{tabular}{lccc}
\hline \multicolumn{1}{r}{ Konsumsi Kafein } & Jumlah & $\begin{array}{c}\text { Persentase } \\
(\mathbf{\%})\end{array}$ \\
\cline { 3 - 3 } & & 86 & 83,5 \\
Kurang Baik & & 17 & 16,5 \\
\hline \multicolumn{2}{r}{ Total } & $\mathbf{1 0 3}$ & $\mathbf{1 0 0 , 0}$ \\
\hline
\end{tabular}

Berdasarkan tabel tersebut, 1gelas/hari yaitu sebesar 17 siswa distribusi konsumsi kafein lebih dari (16,5\%), dari total sampel yaitu 103 1gelas/hari (240ml) didapatkan siswa.

persentase konsumsi kafein lebih dari

Tabel 4. Distribusi Perilaku Menonton TV

\begin{tabular}{|c|c|c|}
\hline Perilaku Menonton TV & Jumlah & $\begin{array}{c}\text { Persentase } \\
(\%)\end{array}$ \\
\hline Baik & 55 & 53,4 \\
\hline Kurang Baik & 48 & 46,6 \\
\hline Total & 103 & 100,0 \\
\hline
\end{tabular}

Berdasarkan tabel tersebut, didapatkan persentase sebesar 55 siswa distribusi perilaku menonton tv kurang (53,4\%) dari total sampel yaitu 103 baik (minimal \pm 5 menit) sebelum tidur siswa.

Tabel 5. Distribusi Kejadian Insomnia

\begin{tabular}{ccc}
\hline Kejadian Insomnia & Jumlah & $\begin{array}{c}\text { Persentase } \\
(\boldsymbol{\%})\end{array}$ \\
\hline Tidak & 3 & 2,9 \\
Ya & 100 & 97,1 \\
\hline Total & $\mathbf{1 0 3}$ & $\mathbf{1 0 0 , 0}$ \\
\hline
\end{tabular}

Berdasarkan tabel tersebut,

2. Hasil Analisis Bivariat

distribusi siswa siswi yang mengalami

Berdasarkan pengolahan data insomnia didapatkan persentase tertinggi sebesar 100 siswa $(97,1 \%)$ dari total sampel yaitu 103 siswa. dengan perhitungan statistik melalui komputer diperoleh hasil penelitian sebagai berikut:

Tabel 6. Hubungan Penggunaan Gadget dengan Kejadian Insomnia

\begin{tabular}{|c|c|c|c|c|c|c|c|}
\hline \multirow{3}{*}{$\begin{array}{c}\text { Lama Penggunaan } \\
\text { Gadget }\end{array}$} & \multicolumn{4}{|c|}{ Kejadian Insomnia } & \multirow{2}{*}{\multicolumn{2}{|c|}{ Total }} & \multirow{3}{*}{ P value } \\
\hline & \multicolumn{2}{|c|}{ Tidak } & \multicolumn{2}{|c|}{ Ya } & & & \\
\hline & $\mathbf{N}$ & $\%$ & $\mathbf{N}$ & $\%$ & $\mathbf{N}$ & $\%$ & \\
\hline Tidak Intens & 1 & 6,2 & 15 & 93,8 & 16 & 100 & 0200 \\
\hline Intens & 2 & 2,3 & 85 & 97,7 & 87 & 100 & 0,388 \\
\hline
\end{tabular}


Dari tabel tersebut, terlihat bahwa responden dengan penggunaan gadget yang intens dan mengalami insomnia sebesar 97,7\%, sedangkan responden dengan penggunaan gadget yang tidak intens dan mengalami insomnia sebesar $93,8 \%$.
Hasil uji statistik didapatkan $p$ value 0,388 pada $\alpha=0,05$ dan nilai dapat disimpulkan bahwa tidak ada hubungan yang bermakna antara lama penggunaan gadget dengan kejadian insomnia pada siswa siswi di SMA Negeri 9 Kota Tangerang Selatan Tahun 2018.

Tabel 7. Hubungan Lama Penggunaan Jejaring Media Sosial dengan Kejadian Insomnia

\begin{tabular}{|c|c|c|c|c|c|c|c|}
\hline \multirow{3}{*}{$\begin{array}{c}\text { Lama Penggunaan } \\
\text { Jejaring Media } \\
\text { Sosial }\end{array}$} & \multicolumn{4}{|c|}{ Kejadian Insomnia } & \multirow{2}{*}{\multicolumn{2}{|c|}{ Total }} & \multirow{3}{*}{ P value } \\
\hline & \multicolumn{2}{|c|}{ Tidak } & \multicolumn{2}{|c|}{$\mathbf{Y a}$} & & & \\
\hline & $\mathbf{N}$ & $\%$ & $\mathbf{N}$ & $\%$ & $\mathbf{N}$ & $\%$ & \\
\hline Singkat & 1 & 3,6 & 27 & 96,4 & 28 & 100 & \\
\hline Sedang & 0 & 0 & 39 & 100,0 & 39 & 100 & 0,350 \\
\hline Lama & 2 & 5,6 & 34 & 94,4 & 36 & 100 & \\
\hline
\end{tabular}

Berdasarkan tabel 7 didapatkan bahwa responden dengan intensitas singkat terhadap penggunaan media sosial dan mengalami insomnia sebanyak 96,4\%, responden dengan intensitas sedang terhadap penggunaan media sosial dan mengalami insomnia sebanyak $100 \%$ dan responden dengan intensitas lama terhadap penggunaan media sosial dan mengalami insomnia sebanyak 94,4\%. Hasil uji Chi Square didapatkan hasil dengan nilai p sebesar 0,350 ( $>0.05)$ menunjukan bahwa hipotesis yang menyatakan tidak ada hubungan intensitas penggunaan jejaring media sosial dengan kejadian insomnia pada siswa siswi di SMA Negeri 9 Kota Tangerang Selatan Tahun 2018.

Tabel 8. Hubungan Konsumsi Kafein dengan Kejadian Insomnia

\begin{tabular}{|c|c|c|c|c|c|c|c|}
\hline \multirow{3}{*}{ Konsumsi Kafein } & \multicolumn{4}{|c|}{ Kejadian Insomnia } & \multirow{2}{*}{\multicolumn{2}{|c|}{ Total }} & \multirow{3}{*}{$P$ value } \\
\hline & \multicolumn{2}{|c|}{ Tidak } & \multicolumn{2}{|c|}{ Ya } & & & \\
\hline & $\mathbf{N}$ & $\%$ & $\mathbf{N}$ & $\%$ & $\mathbf{N}$ & $\%$ & \\
\hline Baik & 3 & 3,5 & 83 & 96,5 & 86 & 100 & \\
\hline Kurang Baik & 0 & 0 & 17 & 100 & 17 & 100 & 0,434 \\
\hline
\end{tabular}

Dari tabel tersebut, terlihat bahwa responden yang mengkonsumsi kafein kurang baik dan mengalami insomnia sebesar 100\%, sedangkan responden 
yang mengkonsumsi kafein dengan baik dan mengalami insomnia sebesar 96,5\%. Hasil uji statistik didapatkan $p$ value 0,434 pada $\alpha=0,05(\mathrm{p}>0.05)$ dan dapat disimpulkan bahwa tidak ada hubungan yang bermakna antara konsumsi kafein dengan kejadian insomnia pada siswa siswi di SMA Negeri 9 Kota Tangerang Selatan Tahun 2018.

Tabel 9. Hubungan Perilaku Menonton TV Sebelum Tidur dengan Kejadian Insomnia

\begin{tabular}{|c|c|c|c|c|c|c|c|}
\hline \multirow{3}{*}{$\begin{array}{l}\text { Perilaku Menonton } \\
\text { TV Sebelum Tidur }\end{array}$} & \multicolumn{4}{|c|}{ Kejadian Insomnia } & \multirow{2}{*}{\multicolumn{2}{|c|}{ Total }} & \multirow{3}{*}{ P value } \\
\hline & \multicolumn{2}{|c|}{ Tidak } & \multicolumn{2}{|c|}{ Ya } & & & \\
\hline & $\mathbf{N}$ & $\%$ & $\mathbf{N}$ & $\%$ & $\mathbf{N}$ & $\%$ & \\
\hline Baik & 1 & 1,8 & 54 & 98,2 & 55 & 100 & 0480 \\
\hline Kurang Baik & 2 & 4,4 & 46 & 95,6 & 48 & 100 & 0,400 \\
\hline
\end{tabular}

Dari tabel 9 tersebut, diketahui responden yang melakukan perilaku menonton tv kurang baik dan mengalami insomnia sebesar 95,6\%, dan responden yang melakukan perilaku menonton tv yang baik dan mengalami insomnia sebesar 98,2\%. Hasil uji statistik didapatkan p-value
0,480 pada $\alpha=0,05(\mathrm{p}>0.05)$ dan dapat disimpulkan bahwa tidak ada hubungan yang bermakna antara perilaku menonton tv dengan kejadian insomnia pada siswa siswi di SMA Negeri 9 Kota Tangerang Selatan Tahun 2018.

\section{PEMBAHASAN}

\section{Hubungan Penggunaan Gadget dengan Kejadian Insomnia}

Berdasarkan hasil penelitian yang telah dilakukan di SMA Negeri 9 Kota Tangerang Selatan, responden dengan penggunaan gadget yang intens dan mengalami insomnia sebesar 97,7\%, sedangkan responden dengan penggunaan gadget yang tidak intens dan mengalami insomnia sebesar 93,8\%. Hasil uji statistik didapatkan $p$ value 0,388 pada $\alpha=0,05$ dan nilai dapat disimpulkan bahwa tidak ada hubungan yang bermakna antara lama penggunaan gadget dengan kejadian insomnia pada siswa siswi di SMA Negeri 9 Kota Tangerang Selatan Tahun 2018. Penelitian ini sejalan dengan penelitian yang dilakukan oleh Sulistiyani (2012) pada mahasiswa semester 2 di FKM Universitas Diponegoro yang memiliki p-value $0,460(\alpha=0,05)$ dimana tidak ada hubungan antara penggunaan gadget dengan kejadian insomnia, maka dengan demikian dapat dikatakan 
bahwa H0 diterima dan Ha ditolak atau tidak ada hubungan yang signifikan antara hubungan lama penggunaan gadget dengan kejadian insomnia.

Peneliti menyebutkan bahwa kemungkinan adanya faktor lain yang menyebabkan insomnia salah satunya adalah lingkungan, salah satu diantaranya lingkungan fisik seperti pencahayaan dan kebisingan disekitar kamar tidur. Hal ini juga sesuai apa yang dikemukakan menurut Nugroho (2010) tentang lingkungan fisik tempat seseorang tidur berpengaruh pada kemampuan seseorang untuk tertidur. Suara, tingkat pencahayaan, suhu ruangan kamar dapat mempengaruhi kualitas tidur. Perbedaan terjadi mungkin karena hanya ada beberapa faktor lingkungan yang digunakan dalam instrumen penelitian seperti kebisingan, cahaya dan teman tidur. Faktor lingkungan tidak hanya didapat dari tiga komponen yang disebutkan sebelumnya namun juga bisa didapat dari suhu ruangan, ventilasi kamar, ukuran, kekerasan dan posisi tempat tidur.

2. Hubungan Lama Penggunaan Jejaring Media Sosial dengan Kejadian Insomnia

$\begin{array}{clc} & \text { Berdasarkan } & \text { hasil } \\ \text { penelitian } & \text { yang dilakukan di } & \text { SMA }\end{array}$
Negeri 9 Kota Tangerang Selatan, responden dengan intensitas singkat terhadap penggunaan media sosial dan mengalami insomnia sebanyak 96,4\%, responden dengan intensitas sedang terhadap penggunaan media sosial dan mengalami insomnia sebanyak 100\% dan responden dengan intensitas lama terhadap penggunaan media sosial dan mengalami insomnia sebanyak 94,4\%. Hasil uji Chi Square didapatkan hasil dengan nilai $\mathrm{p}$ sebesar $0,350(\mathrm{p}>0.05)$ menunjukan bahwa hipotesis yang menyatakan tidak ada hubungan intensitas penggunaan jejaring media sosial dengan kejadian insomnia pada siswa siswi di SMA Negeri 9 Kota Tangerang Selatan Tahun 2018.

Penelitian ini sejalan dengan penelitian yang dilakukan oleh Ariani pada pelajar SMAN 3 Siak Hulu, Riau dengan kualitas tidur buruk sebanyak 28 responden, 13 responden $(31 \%)$ sebagai pengguna jejaring sosial yang rendah dan 15 responden $(34,9 \%)$ sebagai pengguna jejaring sosial yang tinggi. Berdasarkan hasil uji statistik Chi-Square didapatkan $\mathrm{p}$ value $=0,700$ $>(0,05)$, sehingga dapat disimpulkan bahwa tidak ada hubungan yang signifikan antara intensitas penggunaan jejaring sosial dengan kualitas tidur.

Akses jejaring sosial menurut Buente dan Robbin (2008) 
dibagi menjadi 4 dimensi berdasarkan kepentingannya. Dimensi pertama adalah informasi (information utility), yaitu untuk memperoleh informasi atau berita secara online. Yang kedua adalah kesenangan (leisure/fun activities) adalah online dengan alasan yang tidak istimewa, hanya untuk kesenangan atau untuk menghabiskan waktu. Yang ketiga adalah komunikasi (communication), yaitu untuk mengirim dan menerima pesan seperti email. Dan yang ke empat adalah transaksi (transactions), yaitu untuk membeli produk secara online misalnya buku, pakaian dan lain sebagainya.

Menurut peneliti, kemungkinan faktor lain penyebab gangguan tidur selain menggunakan jejaring media sosial, juga cenderung mempunyai keinginan untuk tidur siang yang lebih besar dibandingkan untuk tidur malam. Seorang remaja sering terbangun dimalam hari dan membutuhkan banyak waktu untuk jatuh tertidur pola tidur mengalami perubahan yang khas bagi kalangan remaja. Faktor ini juga di dukung oleh penelitian yang dilakukan oleh Nugroho (2010) sebelumnya

Meini (2016) berpendapat bahwa, sebagian besar responden remaja berada pada insomnia jangka pendek yang berlangsung selama 1-4 minggu disebabkan karena rokok yang dikonsumsi dalam sehari dapat mencapai 5-14 batang rokok, dimana kebanyakan remaja-remaja tersebut merokok pada malam hari saat sedang bersama dengan teman-teman sebayanya sebelum mereka beristirahat untuk tidur. Hal ini menyebabkan mereka mengalami gejala-gejala insomnia seperti kesulitan untuk memulai tidur, mempertahankan tidur dengan jam tidur yang maksimal atau sering terbangun pada malam hari. Karena pada dasarnya nikotin pada otak akan hilang dalam waktu 30 menit namun reseptor otak seorang perokok yang dapat menghabiskan 5-14 batang rokok dalam sehari seolah akan menagih nikotin itu lagi dan lagi hingga mampu mengganggu proses tidur itu sendiri.

3. Hubungan Konsumsi Kafein dengan Kejadian Insomnia

Berdasarkan hasil penelitian yang dilakukan di SMA Negeri 9 Kota Tangerang Selatan, responden yang mengkonsumsi kafein kurang baik dan mengalami insomnia sebesar $100 \%$, sedangkan responden yang mengkonsumsi kafein dengan baik dan mengalami insomnia sebesar $96,5 \%$. Hasil uji statistik didapatkan $p$ - 
value 0,434 pada $\alpha=0,05(\mathrm{p}>0.05)$ dan dapat disimpulkan bahwa tidak ada hubungan yang bermakna antara konsumsi kafein dengan kejadian insomnia pada siswa siswi di SMA Negeri 9 Kota Tangerang Selatan Tahun 2018.

Penelitian ini sejalan dengan Monica Purdiani (2014) terhadap pola tidur di Universitas Surabaya dimana memiliki p-value 41,7 dengan perbandingan nilai Chi-Square tabel (df $6=5,991)$ dimana tidak ada hubungan konsumsi kafein dengan kejadian insomnia.

Menurut peneliti, faktor lain dari konsumsi kafein adalah dari kerentanan responden terhadap konsumsi kafein sendiri, setiap orang mempunyai kerentanan terhadap efek kafein yang berbeda-beda, faktor ini sesuai dengan penelitian sebelumnya yang dikemukakan oleh Adelina Haryono (2009) dimana setiap orang punya kerentanan terhadap kafein yang berbeda-beda terhadap gangguan tidur.

Selain faktor kerentanan responden, status gizi juga bisa mempengaruhi gangguan tidur pada remaja, berdasarkan hasil penelitian 30 responden obesitas didapati bahwa, 26 reponden $(86,7 \%)$ memiliki kualitas tidur buruk. Hal ini disebabkan dampak yang ditimbulkan akibat obesitas adalah dapat menyebabkan gangguan pernafasan sleep apnea, diabetes melitus, panyakit kardiovaskuler, hipertensi. Sleep apnea yang ditandai dengan mendengkur dan kantuk berlebih merupakan gangguan tidur yang paling berbahaya saat ini sehingga dapat mempengaruhi kualitas tidur anak usia remaja, gangguan tidur yang terjadi pada anak dan remaja sering diabaikan oleh orang tua, padahal dampak dari gangguan tidur yang terjadi dapat mempengaruhi fungsi kognitif dan perilaku sehari hari, mengakibatkan terjadinya rasa kantuk yang berlebihan dan penurunan tingkat perhatian di siang hari sehingga dapat mempengaruhi kualitas tidur anak (Budianti, 2011).

Penelitiaan Rahman (2012) juga mengemukakan bahwa hubungan obesitas dengan risiko obstructive sleep apnea (OSA) pada remaja di SMAN 1 Purwokerto, terdapat hubungan yang signifikan antara obesitas pada remaja dengan risiko Obstructive Sleep Apnea (OSA) di SMAN 1 Purwokerto dengan hasil $p$ value $0,000<\alpha=0,05$. Hal ini disebabkan hampir sebagian besar responden Remaja obesitas sewaktu tidur cenderung mengalami gangguan tidur mendengkur. Keadaan mendengkur saat tidur tentunya belum 
bias dikatakan sebagai akibat dari OSA semata, masih mungkin ada faktor kelelahan ataupun kondisi medis lainnya, meski demikian gangguan tidur mendengkur pada remaja.

\section{Hubungan Perilaku Menonton TV Sebelum Tidur dengan Kejadian Insomnia}

Berdasarkan hasil penelitian yang dilakukan pada siswa siswi kelas $\mathrm{X}$ di SMA Negeri 9 Kota Tangerang Selatan, responden yang melakukan perilaku menonton tv kurang baik dan mengalami insomnia sebesar 95,6\%, dan responden yang melakukan perilaku menonton tv yang baik dan mengalami insomnia sebesar 98,2\%. Hasil uji statistik didapatkan p-value 0,480 pada $\alpha=0,05(\mathrm{p}>0.05)$ dan dapat disimpulkan bahwa tidak ada hubungan yang bermakna antara perilaku menonton tv dengan kejadian insomnia pada siswa siswi di SMA Negeri 9 Kota Tangerang Selatan Tahun 2018.

Penelitian ini sejalan dengan penelitian yang dilakukan oleh Adelina Haryono (2009) dimana memiliki $p$ value $0,371(\alpha=0,05)$ yang artinya tidak ada hubungan yang bermakna antara kegiatan menonton TV sebelum tidur dengan kejadian insomnia.
Menurut peneliti, faktor lain yang menyebabkan kualitas tidur seperti tekanan darah yang dimiliki responden juga berpengaruh pada gangguan tidur, faktor tersebut juga sejalan dengan penelitian yang dikemukakan oleh Luthfi (2017) yang dilakukan pada pelajar SMA Negeri 10 Padang didapatkan hasil bahwa terdapat perbedaan kualitas tidur yang baik maupun buruk dengan tekanan darah sistolik maupun diastolic $(\mathrm{p}<0,05)$.

Terdapat perbedaan rata-rata tekanan darah sistolik antara kualitas tidur baik dengan kualitas tidur buruk sebesar 8,32 $\mathrm{mmHg}$, dimana tekanan sistolik dengan kualitas tidur buruk cenderung lebih tinggi.

Terdapat perbedaan rata-rata tekanan darah diastolik antara kualitas tidur baik dengan kualitas tidur buruk sebesar 6,06 mmHg dimana kualitas tidur buruk cenderung lebih tinggi. Hal ini sesuai dengan penelitian Javaheri et al (2008), dimana remaja dengan kualitas tidur yang buruk mengalami peningkatan tekanan darah sistolik sebesar $4 \pm 1,2 \mathrm{mmHg}$ dan diastolik sebes ar 1,7 $\pm 1,2 \mathrm{mmHg}$.

\section{SIMPULAN}

Berdasarkan hasil penelitian hubungan penggunaan gadget dengan kejadian insomnia pada siswa kelas X SMA Negeri 
9 Kota Tangerang Selatan, maka dapat diambil kesimpulan antara lain sebagai berikut:

1. Distribusi responden dengan penggunaan gadget yang intens dan mengalami insomnia sebesar $97,7 \%$, sedangkan responden dengan penggunaan gadget yang tidak intens dan mengalami insomnia sebesar 93,8\%. Hasil uji statistik didapatkan $p$-value 0,388 pada $\alpha=0,05$ dan nilai dapat disimpulkan bahwa tidak ada hubungan yang bermakna antara lama penggunaan gadget dengan kejadian insomnia pada siswa siswi di SMA Negeri 9 Kota Tangerang Selatan Tahun 2018.

2. Distribusi responden dengan intensitas singkat terhadap penggunaan media sosial dan mengalami insomnia sebanyak 96,4\%, responden dengan intensitas sedang terhadap penggunaan media sosial dan mengalami insomnia sebanyak 100\% dan responden dengan intensitas lama terhadap penggunaan media sosial dan mengalami insomnia sebanyak $94,4 \%$. Hasil uji Chi Square didapatkan hasil dengan nilai $\mathrm{p}$ sebesar $0,350(\mathrm{p}>0.05)$ menunjukan bahwa hipotesis yang menyatakan tidak ada hubungan intensitas penggunaan jejaring media sosial dengan kejadian insomnia pada siswa siswi di SMA Negeri 9 Kota Tangerang Selatan Tahun 2018.

3. Distribusi responden yang mengkonsumsi kafein kurang baik dan mengalami insomnia sebesar $100 \%$, sedangkan responden yang mengkonsumsi kafein dengan baik dan mengalami insomnia sebesar 96,5\%. Hasil uji statistik didapatkan p-value 0,434 pada $\alpha=0,05(\mathrm{p}>0.05)$ dan dapat disimpulkan bahwa tidak ada hubungan yang bermakna antara konsumsi kafein dengan kejadian insomnia pada siswa siswi di SMA Negeri 9 Kota Tangerang Selatan Tahun 2018.

4. Distribusi responden yang melakukan perilaku menonton tv kurang baik dan mengalami insomnia sebesar 95,6\%, dan responden yang melakukan perilaku menonton tv yang baik dan mengalami insomnia sebesar 98,2\%. Hasil uji statistik didapatkan $p$-value 0,480 pada $\alpha=0,05(\mathrm{p}>0.05)$ dan dapat disimpulkan bahwa tidak ada hubungan yang bermakna antara perilaku menonton tv dengan kejadian insomnia pada siswa siswi di SMA Negeri 9 Kota Tangerang Selatan Tahun 2018.

5. Penggunaan gadget pada responden siswa siswi SMA Negeri 9 Kota Tangerang Selatan dengan kejadian insomnia tidak terjadi hubungan yang 
signifikan karena p-value yang didapatkan dari hasil uji Chi-Square menunujukkan nilai $0,388 \quad(\alpha=0,05)$ dimana H0 diterima.

\section{DAFTAR PUSTAKA}

Ariani, Mutia. Hubungan Intensitas

Penggunaan Jejaring Sosial

Terhadap Kualitas Tidur

Remaja Di Sman 3 Siak.

Univaersitas Riau. [E-Journal].

Available from URL:

https://repository.unri.ac.id/xmlu/b

itstream/handle/123456789/4298/

Manuskrip\%20HUBUNGAN\%20

INTENSITAS\%20PENGGUNAA

N\%20JEJARING\%20SOSIAL.pd

f? sequence $=1$

Budianti. (2011). Analisis Faktor Penyebab Obesitas Pada Anak Usia Sekolah. Skripsi Universitas Indonesia. Available from URL: http://lontar.ui.ac.id/file=digital/ 20280289-T\%20Budianti.pdf

Fadilah, A. (2011). Pengaruh

Penggunaan Alat Komunikasi Handphone (HP) terhadap Aktivitas Belajar Siswa SMP Negeri 66 Jakarta Selatan (skripsi). Fakultas Tarbiyah dan Ilmu Keguruan Jurusan Pendidikan Agama Islam Universitas Islam Negeri Syarif Hidayatullah, Jakarta.

Haryono, Adelina. (2009). Prevalensi

Gangguan Tidur pada Remaja Usia 12-15 Tahun di Sekolah Lanjutan Tingkat Pertama. (serial online). E-jurnal form URL:https://saripediatri.org/index. php/sari-pediatri/article/view/585
Kominfo. (2014). Siaran Pers Kominfo. https://kominfo.go.id/index.php/co ntent/detail/3980/Kemkominfo\%3 A+Pengguna+Internet+di+Indones ia+Capai+82+Juta/0/berita_satker

Kominfo. (2014). Available from $U R L:$ https://kominfo.go.id/index.p $\mathrm{hp} /$ content/detail/12640/siaranpers-no-53hmkominfo022018 tentang-jumlah-pengguna-internet 2017-meningkat-

kominfoterus- lakukanpercepatan-pembangunanbroadband/0/siaran_pers

Luthfi, Muhammad. (2017).Hubungan Kualitas Tidur dengan Tekanan Darah pada Pelajar Kelas 2 SMA Negeri 10 Padang. FKM Andalas: Padang. [E- Journal]. Available fromURL:http://jurnal.fk.unand.ac .id/index.php/jka/article/view/698

Nugroho, (2010), Keperawatan gerontik dan geriatrik. Jakarta: Penerbit Buku Kedokteran EGC

Purdiani, Monica. (2014). Hubungan Penggunaan Minuman berkafein terhadap pola tidur dan pengaruhnya pada tingkah laku mahasiswa universitas Surabaya. Fakultas Farmasi: Universitas Surabaya. [E-Journal]. Available from URL:http://download. portalgaruda.org/article.php?articl $\mathrm{e}=175563 \& \mathrm{val}=5455 \&$ title $=$ HUB UNGAN\%20PENGGUNAAN\%2 OMINUMAN\%20BERKAFEIN\% 20TERHADAP\%20POLA\%20TI DUR\%20DAN\%20PENGARUH NYA\%20PADA\%20TINGKAH\% 20LAKU\%20MAHASISWA/I\%2 OUNIVERSITAS\%20SURABAY A

Rafknowledge .(2004). Insomnia dan Gangguan Tidur Lainnya. Jakarta : PT.Elex. Media Komputindo. 
Rahman. (2012). Hubungan Obesitas Dengan Risiko Obstructive Sleep Apnea (Osa) Pada Remaja. Jurnal Keperawatan Poltekkes Kemenkes Semarang.http://www.download.p ortalgaruda.org/article.php?article $=65821 \& \mathrm{val}=47$

$92 \&$ title $=44$

HUBUNGANOBESITAS

DENGANRISIKO

OBSTRUCTIVESLEEPAPNEA

(OSA)PADAREMAJA.pdf

Robbin, A \& Buente, Wayne,

(2008). Trends in Internet

Information Behavior:

2000-2004. Journal of the

America Society forr Information

Science. Available from

$U R L:$ http://palimpsest.fisip.unair.a

c.id/images/pdf/astutik.pdf.

Sulistiyani, Cicik. (2012). Beberapa

Faktor Yang Berhubungan

Dengan Kualitas Tidur Pada

Mahasiswa Fakultas Kesehatan

Masyarakat Universitas

Diponegoro Semarang. FKM

Undip. [E-Journal]. Available

from URL:

http://download.portalgaruda.org/a

rticle.php? article $=73879 \& \mathrm{val}=470$

0\&title 